\title{
MENGEMBANGKAN TOLERANSI SISWA MENGGUNAKAN FILM DOKUMENTER
}

\author{
Wika Tri Utami \\ Universitas Negeri Semarang \\ Email: wikatriutami@gmail.com
}

\begin{abstract}
Abstrak
Toleransi merupakan kunci hidup damai ditengah keberagaman budaya, agama, dan etnis. Toleransi dan kepedulian saling berkaitan, sehingga dalam pengembangannya harus berdasarkan pengalaman langsung, atau situasi nyata di sekitar siswa. Film dokumenter merupakan media yang diprediksi dapat digunakan untuk mengembangkan sikap toleransi, karena menyajikan situasi apa adanya, tanpa ada nilai benar atau salah. Penggunaan film dokumenter dapat membantu siswa melakukan refleksi dari berbagai kejadian yang ada di sekitarnya, berkenaan dengan pentingnya sikap toleransi dalam menciptakan perdamaian. Penggunaan film dokumenter dapat dilakukan dalam dua cara yaitu 1) sebagai media dalam bimbingan klasikal, atau 2) menugaskan kepada siswa sebagai kegiatan project based learning.
\end{abstract}

Kata kunci : Film Dokumenter, Toleransi.

\section{PENDAHULUAN}

Toleransi merupakan inti dari kompetensi multikultural yang harus dimiliki siswa. Keberagaman budaya di Indonesia merupakan sesuatu yang harus diterima dan diapresiasi, bukan untuk diperdebatkan. Sikap intoleran menyebabkan banyak sekali konflik antar suku bangsa, ras, dan pemeluk agama.

Data temuan Wahid Foundation menunjukkan angka intoleran di Indonesia lebih dari $50 \%$. Hal ini menyebabkan ketidakmauan seseorang untuk dekat dengan orang yang berbeda dengannya. Intoleransi dapat terjadi bukan hanya pada pemeluk agama yang berbeda, melainkan juga pada orang yang memiliki agama yang sama. Hal tersebut didukung oleh temuan Wahid Foundation di tahun 2016, bahwa provinsi Aceh memiliki presentase toleransi yang lebih rendah dibandingkan Kalimantan.

Toleransi bukan hanya berhubungan dengan cara seseorang menyikapi perbedaan, tetapi juga akar dari hidup damai. Tillman (Supriyanto \& Wahyudi, 2017) menjelaskan karakter toleransi sebagai sikap saling menghargai melalui pengertian dengan tujuan kedamaian. Toleransi adalah menuju kedamaian. Toleransi disebut sebagai faktor esensi untuk perdamaian.

Bimbingan dan konseling memiliki fungsi pencegahan dan pengembangan, yang berfokus kepada pengembangan karakter 
positif agar siswa dapat merasakana kesejahteraan psikologis dan hidup damai. Guru BK dapat menggunakan strategi bimbingan ataupun konseling dalam pengembangan karakter siswa yang toleran. Silondae (2013) berpendapat melalui layanan bimbingan kelompok, siswa memperoleh kesempatan mengembangkan sikap-sikap positif seperti toleransi, kerjasama, dan tanggung jawab. Sedangkan stretegi konseling digunakan untuk membantu siswa mengatasi hambatan dalam dirinya saat menghadapi perbedaan budaya.

Pemanfaatan media film merupakan alternatif dari strategi bimbingan dan konseling. Nursalim (2013) berpendapat bahwa sebagai media bimbingan film disebut juga gambar hidup (motion pictures), yaitu serangkaian gambar diam (still pictures) yang meluncur secara cepat dan diproyeksikan sehingga menimbulkan kesan hidup dan bergerak. Oleh karenanya, film memberikan kesan yang impresif bagi pemirsanya, memberikan kesan yang realistis, dan dapat merubah sikap siswa yang menontonnya.

Dalam tulisan ini akan difokuskan kepada penggunaan film dokumenter sebagai media bimbingan dalam mengembangkan sikap toleransi siswa. Film dokumenter berisi gambaran yang lebih nyata, dan diambil dari situasi nyata. Berbagai film dokumenter mengenai toleransi diambil dari persoalan - persoalan budaya mulai dari stigmatisasi, hingga konflik antar budaya. Kondisikondisi itulah yang akan mengasah nilai moral siswa dan menjadi pendorong agar siswa lebih toleran terhadap perbedaan.

\section{PEMBAHASAN}

a. Aspek Toleransi.

Toleransi seringkali disalah artikan dengan membiarkan begitu saja. Pada hakikatnya toleransi adalah usaha untuk membangun hubungan dan kepercayaan. Oleh karena itu toleransi bukan berarti serba boleh, karena itu berarti mengingkari hubungan kesetaraan dan kepercayaan.

Jati (2014) berpendapat bahwa toleransi adalah kemampuan untuk memberikan tujuan dan sikap yang adil walaupun berbeda pendapat, perilaku, ras dan agama. Toleransi lebih mengarahkan manusia untuk menunjukkan rasa hormat terhadap perbedaan masing-masing manusia, bukan sekedar mengabaikan perbedaan.

Berdasarkan konsep tersebut aspek toleransi dapat dibatasi pada tiga hal yaitu 1) aspek perdamaian, 2) aspek penghormatan terhadap perbedaan dan individu, dan 3) aspek kesadaran. Secara rinci dan operasional, Mahpudz, Jamaludin, \& Palimbong (2018) menguraikan setiap aspek sebagai berikut.

1. Aspek Perdamaian . Toleransi merupakan penerimaan terhadap perbedaan, sekalipun tidak setuju atau tidak suka. Dengan menerima perbedaan seseorang akan merasakan kedamaian dan terhindar dari konflik, karena perasaan berbeda, berbeda kepentingan, kebutuhan, tujuan maupun hasil yang diperoleh mendorong terjadi konflik. Ciri 
dari aspek ini adalah kepedulian, keberanian, dan cinta.

2. Apsek Apresiasi. Toleransi pada hakikatnya mengarahkan kita untuk menghagai perbedaa manusia. Oleh karena itu, toleransi dapat terlihat dari cara kita saling menghormati, menghargai perbedaan orang lain, dan menghargai diri.

b. Aspek Kesadaran.

Dalam bertoleransi, diperlukan kesadaran untuk menolak segala bentuk kekerasan dan pelanggaran HAM, kemampuan untuk berbagi dan menghormati, keterbukaan dan komunikasi, dan toleransi terhadap perbedaan etnis, budaya dan agama

Film dokumenter sebagai media edukasi multikultural film dokumenter merupakan film yang menyajikan situasi nyata apa adaya. Salim \& Erandaru (2019) mengemukakan bahwa film dokumenter memiliki kunci utama dalam pembuatannya yaitu penyajian fakta. Film dokumenter tidak menciptakan suatu peristiwa atau kejadian, namun merekam peristiwa yang sungguh-sungguh terjadi. Hal itu berhubungan dengan tokoh, obyek, momen dan peristiwa yang nyata.

Umumnya film dokumenter tidak memiliki tokohprotagonis maupun antagonis, konflik dan penyelesaiannya. Struktur bertutur dalam film dokumenter memiliki tujuan yang sederhana yakni agar memudahkan penonton untuk memahami dan mempercayai faktafakta yang disajikan (Salim \& Erandaru, 2019)
Penggunaan film sebagai media dalam mengajarkan kompetensi multrikultural sudah banyak diteliti. Nittoli \& Guiffrida (2017) menemukan ketika film diimplementasikan bersamaan dengan kegiatan pembelajaran reflektif, terbukti efektif dalam meningkatkan kompetensi multikultural dan keadilan sosial siswa. Dalam penelitian tersebut peserta melaporkan bahwa kegiatan pedagogik efektif dalam menghidupkan konsep-konsep teori multikultural dan merangsang percakapan yang sulit tetapi perlu mengenai ras, etnis, hak istimewa, dan kekuasaan.

Sementara itu, Villalba \& Redmond (2008) menyatakan film yang menempatkan penonton dalam situasi yang tidak memiliki solusi benar dan salah dapat memabantu dalam merefleksikan nilai - nilai. Film dokumenter menyajikan situasi apa adanya tanpa ada benar dan salah, sehingga siswa akan memunculkan reaksi terhadap situasi yang ditampilkan, selain itu dengan sendirinya akan bertanya - tanya dan membangun pemahaman sendiri akan nilai perbedaan budaya yang dilihatnya.

Febriyati, Darmawani, \& Suryahadikusumah (2019) berpendapat pembuatan film membuat siswa bertemu secara langsung dengan kondisi bermasalah yang merangsang mereka untuk mempertanyakan mengapa sampai terjadi masalah, bagaimana hal ini terjadi, dan apa akibatnya. Oleh karena itu melalui pembuatan film dokementer, siswa akan secara langsung memahami makna toleransi 
dan dampaknya jika toleransi tidak menjadi kebiasaan.

c. Penggunaan film dokumenter dalam layanan bimbingan untuk meningkatkan toleransi.

Penggunaan film dokumenter dalam layanan bimbingan dapat dilakukan dengan dua cara, yaitu menggunakan film sebagai media yang ditampilkan dalam bimbingan klasikal. Guru BK memilih film dokumenter yang menceritakan konflik antar budaya yang didasari kejadian intoleran, meminta siswa untuk menyimak, dan diakhiri dengan diskusi mengenai bagaimana toleransi memegang peranan penting untuk suasana damai.

Cara kedua, guru BK dapat melakukan penugasan membuat film dokumenter ketika bimbingan klasikal sebagai projct based learning (PBL). Siswa dibagi pada kelompok proyek, dan memilih situasi keberagaman di lingkunga sekitar mereka.

Langkah- langkah PBL dalam kegiatan bimbingan klasikal antara lain sebagai berikut.

1. Menentukan Pertanyaan mendasar. Bimbingan dimulai dengan pertanyaan esensial, yaitu pertanyaam yang dapat memberi penugasan peserta didik dalam melakukan aktivitas, seperti "apakah kita menginginkan suasana yang damai?", "bagaimana caranya kita dapat hidup damai, di tengah- tengah keberagaman?.

2. Mendesain perencanaan proyek. Perencanaan dilakukan secara kolaboratif antara guru BK dan peserta didik, bahkan dapat melibatkan guru kesenian, sosiologi, atau kewarganegaraan.

3. Menyusun jadwal . Guru BK bersama siswa menyusun jadwal aktivitas dan target dalam menyelesaikan proyek.

4. Memonitor kemajuan proyek. Dalam sesi sesi bimbingan klasikal selanjutnya siswa melaporkan kemajuan proyek dan diberikan umpan balik oleh guru BK.

5. Menguji hasil. Film dokumenter yang berhasil dibuat ditonton bersama - sama, kemudian diuji seberapa besar berpengaruh kepada pandangan dan perasaan siswa mengenai hidup bertoleransi.

\section{PENUTUP/ KESIMPULAN}

Mengembangkan toleransi pada hakikatnya meningkatkan rasa peduli dan menghargai. Oleh karena itu upaya pengembangan yang harus dilakukan oleh layanan BK sebaiknya menggunakan situasi nyata yang dapat direfleksikan dalam kehidupan siswa. Berdasarkan kajian tersebut, film dokumenter memiliki kelebihan untuk mengembangkan toleransi siswa, karena film dokumenter menyajikan gambaran situasi apa adanya tentang keberagaman dan kedamaian yang bersumber dari sikap toleransi masyarakat.

\section{DAFTAR PUSTAKA}

Febriyati, Z., Darmawani, E., \& Suryahadikusumah, A. R. (2019). Meningkatkan Kemampuan Siswa Dalam Beretika Melalui Pembuatan Film Pendek (Studi Eksperimen 
Semu Di SMAN 1 Tungkal Ilir). JUANG: Jurnal Wahana Konseling, 2(1), 70-78.

Jati, W. R. (2014). Toleransi Beragama Dalam Pendidikan Multikulturalisme Siswa SMA Katolik Sang Timur Yogyakarta. Cakrawala Pendidikan, Februari 2014, XXXIII (1).

Mahpudz, A., Jamaludin, \& Palimbong, A. (2018). Strengthening The Tolerance Attitude As A Basis Of Social Studies Education And Preparing The Competencies Of 21St Century Students. The 3rd International Seminar on Social Studies and History Education (ISSSHE), (pp. 239-245).

Nittoli, J., \& Guiffrida, D.( 2017). Using Popular Film to Teach Multicultural Counseling: A Constructivist Approach. Journal of Creativity in Mental Health 1-14.

Nursalim, M. (2013). Pengembangan Media Bimbingan dan Konseling. Jakarta: indeks.

Salim, Y. A., \& Erandaru, E. (2019). Perancangan Film Dokumenter Tentang Fenomena Budaya Etnis Tionghoa di Pasar Semawis Semarang. . Jurnal DKV Adiwarna, 1(14), 10.

Silondae, D. P. (2013). Model Bimbingan Kelompok Berbasis Nilai Budaya Suku Tolaki untuk Meningkatkan Keterampilan Sosial Siswa. Jurnal Bimbingan Konseling, 2(2).

Supriyanto, A., \& Wahyudi, A. (2017). Skala karakter toleransi: konsep dan operasional aspek kedamaian, menghargai perbedaan dan kesadaran individu. Counsellia: Jurnal Bimbingan dan Konseling, 7(2), 61-70.

Villalba, J. A., \& Redmond, R. E. (2008). Crash: Using a popular film as an experiential learning activity in a multicultural counseling course. Counselor Education and Supervision, 47(4), 264-276. 